\title{
放射線治療に伴う正常細組織障害
}

\author{
浅 井昭雄松谷雅生 高倉 公朋
}

\section{Radiation-induced Damages to the Brain}

by

Akio Asai, M.D., Masao Matsutani, M.D., and Kintomo Takakura, M.D.

from

Department of Neurosurgery, University of Tokyo

Radiation-induced damage to the brain has been reviewed etiologically and histopathologically, based on reports in the literature and our own data. Recently, instances of late delayed radiation necrosis of the normal brain and acute brain edema have become less common, since therapists are adhering to standard radiation doses and fractionation, whereas instances of radiation-induced brain atrophy (leukoencephalopathy) are becoming a common problem. This pathologic state can be induced in the normal brain by as low a dose as $30 \mathrm{~Gy}$, so that cases of radiation-induced atrophy are innevitable unless therapists recognize this problem and prevent it. The etiology, histologic findings, and clinical significance of this pathologic entity are discussed.

(Received \& accepted January 31, 1992)

Key words : brain tumor, radiation therapy, leukoencephalopathy, brain atrophy, radiation necrosis

Jpn J Neurosurg (Tokyo) 1:116-122, 1992

\section{はじめに}

悪性腫瘍の治療成績は集学的治療の進歩の結果, 一般 にここ 10 年間に目覚ましく向上し, 胃癌や小児急性リン パ性白血病などでは治癒しうるまでに至っている。悪性 脳腫瘍の治療成績も顕微鏡,レーザーメス, CUSA（超音 波メス),など新しい手術器械の導入とそれに伴う手術法 の進歩, コンピュータ導入による conventional radiotherapy の精度の向上, 術中照射 ${ }^{28)}$, 組織内照射などの併 用, 新しい作用機序の化学療法剤, 免疫療法の併用など により，はかばかしいとはいえないまでも，少しずつで はあるが着実に向上してきた ${ }^{36)}$.

これら治療成績の向上に伴って, 病巣周辺の機能ある いは形態の温存など，生存の質（quality of life）をも鑑
みた治療内容が要求されるようになってきている。脳機 能の保存は以前からも重視されており, 悪性脳腫場治療 ではこれまでにも周囲の脳組織をできるだけ温存し，し かも治療成績は向上させようということで, 手術では消 極的に切除し, 放射線治療あるいは化学療法で残存腫瘍 および将来再発するであろう遠隔の潜在的浸潤部をも含 めて広範囲にしかも徹底的にたたくという基本原則が採 られてきて抢り，つい一時期前まではグリオブラストー マに対して全脳に 50〜 $60 \mathrm{~Gy}$ が照射されていた。しか し，この背景には「脳は手術で無理をすると障害が残る が，放射線照射では $50 〜 60 \mathrm{~Gy}$ までなら安全で障害は出 ない」という放射線による正常脳障害に対する過小評価 があったと考えられる。なぜなら，近年われわれが報告 した subacute radiation-induced leukoencephalopathy (radiation-induced brain atrophy) は，治療家が安全な

東京大学医学部脳神経外科〔連絡先：浅井昭雄, テ 105 東京都中央区築地 5-1-1, 国立がんセンター研究所生物物理部〕

Address reprint requests to: Akio Asai, M.D., Biophysics Division, National Cancer Center, 5-1-1 Tsukiji, Cyuo-ku, Tokyo 105, Japan 
線量 (tolerable dose) と考えている $30 \mathrm{~Gy}$ 程度の被爆 でも起こり得, 照射範囲に比例して障害される脳の範囲 も広くなり, あわせて臨床症状も重篤になってくること がわかってきたからである゙て4).

この意味で, 従来, 腫瘍に対しては conservative therapy の一つといわれている放射線治療の方が, 正常脳に 対しては手術よりむしろ radical であるといえ, 全脳照 射などに至っては腫瘍も正常脳組織も見境なく傷害して しまう無差別爆撃といっても過言ではないであろう。化 学療法についても同様の理屈があてはまる.したがって, 高い quality of life の維持という治療上の要求を満たす ためには, 治療家が放射線治療や化学療法による正常脳 組織障害を再認識し，それらをふまえて，先に述べた悪 性脳腫瘍治療の基本原則を再検討することが必要であ る.

本稿では主として放射線による細胞レベルでの障害お よびその結果引き起こされる正常脳組織の障害について 解説し，それらの認識をいかに治療に反映しうるかにつ いて述べる。

\section{放射線による 細胞傷害の分子生物学的メカ二ズし}

放射線による種々の障害を理解するうえで細胞レベル での放射線の作用について知っておく必要がある。われ われが通常, 放射線と言っているのは $\gamma$ 線などの電離放 射線で，その直接の作用点は原子，分子であり，そこで 電離あるいは励起を引き起こし，また，各種のフリーラ ジカルを産生する ${ }^{14)}$. これらの化学的変化が細胞を構成 する種々の高分子物質や水に起こることにより, 生化学 的あるいは分子生物学的反応の狂いを生み, 細胞の機能 の低下や分裂の異常をきたす。これらが，細胞の集合体 として機能をもつ組織レベルで起こった時に生体の機能 障害となって現われる。

細胞レベルで放射線の標的となる高分子として，蛋白 質（酵素）と核酸が考えられる。蛋白質に対してはシス テイン同士の間の S-S 結合を電離, 励起により切断する ことにより二次および三次構造を変化させ，その作用を 失活させると考えられる．また，水から生じたラジカル によって引き起こされる二次, 三次構造の変化も大きな 役割を果たすと考元られる。核酸に対しては主として隣 接するヌクレオチド間の結合であるリン酸と五炭糖の間 のフォスフォジエステル結合を電離により切ることによ り, DNA 鎖の切断を引き起こす.水から生じたラジカル も同様な切断を引き起こす。電離放射線による DNA 鎖
の切断には一重鎖切断と二重鎖切断がある. $\gamma$ 線のよう に LET (linear energy transfer), すなわち荷電粒子あ るいは光子がその飛跡に沿って単位長さ当りの局所に与 えうるエネルギー量が, 低い放射線では主として一重鎖 切断が起こり, 逆に $\alpha$ 線, $\beta$ 線のように高 LET の放射 線, あるいは低 LET の放射線でも高線量ならば二重鎖 切断を起こしうる.

一重鎖切断はその大部分が細胞内の DNA 修復酵素に よって修復され，その練胞自体が致死的となることは少 ないが，修復の際に mislinkage が起こって cross linkage を作ったり，遺伝子の recombination が起こった りすると，細胞分裂に支障をきたしたり，発癌にも関与 してくると考えられる ${ }^{14)}$. また, S 期にある細胞では一重 鎖切断でも重大な障害が起こりうる，なぜなら， S 期で はDNA 鎖全域にわたって一重鎖の状態のDNA の割合 が多く, DNA が低 LET の線種あるいは低線量でも容 易に寸断されてしまうからであり，しかも，S 期は各種 DNA ポリメラーゼの活躍の主座であり，それらと作用 点を同じくするDNA 修復酵素（おそらくはDNA polymerase の subtype) の活性は低下していることが予想さ れるからである，仮に細胞が致死的にならないまでも， 分裂の障害や，次代の細胞での重篤な機能障害を引き起 こしうると考えられる。したがって, turn over の盛ん な $\mathrm{S}$ 期分画の大きな細胞では放射線感受性が高いことに なる，脳の場合は proliferating pool に入っている細胞 は血管内皮細胞と glial cell の一部のみで, oligodendrocyte が比較的感受性が高いといわれている。

二重鎖切断は一重鎖切断に比して修復されにくく, 多 数起こり DNA が寸断されると致死的となる。癌を治療 する立場から考えると, 腫锡細胞では二重鎖切断がより 多く発生することを期待するわけであるが，われわれが 通常使用している $\gamma$ 線による外照射法では二重鎖切断 を起こすには 1 回照射量, 総線量ともに現在より一桁高 い量が必要であり, 放射線による直接効果としては一重 鎖切断による効果しか得られていないことになる.

\section{放射線による組織障害のメカニズム}

細胞レベルの障害から組織レベルの障害になると系は さらに複雑になるが，先に述べた細胞に対する直接障害 以外に間接障害の関与が大きくなる。すなわち, 主とし て血管の障害を介した細胞障害である。血管内皮細胞は turn over が盛んで, 放射線感受性が比較的高い細胞の 一つであり, 培養細胞では数 Gy の single dose で増殖 能の低下および形態学的変化をきたすことがわかってい 
る ${ }^{19)}$ ．血管内皮の傷害により毛細管レベルで血管透過性 の六進 ${ }^{913320212325) 29}$ と血管内凝固による血管閉塞 ${ }^{1110322}$ が 起こりうる. 血管透過性の亢進は, 脳では他臟器に比し て重要な意義をもつ。一つは脳浮腫の発生による頭蓋内 圧の上昇であり，もう一つは血液脳関門の破壊によって 直接血中有害物質に接触することによる神経組織の傷害 である，血管透過性の充進は, 実験的には動物種や臟器 にもよるが, $10 \mathrm{~Gy}$ 前後の single dose で起こるとする ものが多い ${ }^{925)}$. 臨床的には CT 上の軽微な脳浮腫は 2 Gy ずつの分割照射でも $20 \mathrm{~Gy}$ 前後になると起こりう る。この病態は後に述べる subacute radiation-induced leukoencephalopathy の一因とも考えられる.

放射線照射により血管内凝固，閉塞に至るまでの組織 学的変化が諸家により詳細に検討されている ず，血管内皮の細胞質の濃縮と小型化が起こり，核の濃 縮（piknosis）に次いで細胞が基底膜より脱落してしま う。この部位に血小板が凝集し, 次いで血小板ーフィブ リン塊ができ毛細管を閉塞することにより，その灌流領 域に虚血性壊死巣を生じる，脳腄瘍に対する放射線治療 効果の大部分はこのメカニズムによるものであり, 次に 述べる late delayed radiation necrosis の発生にも関与 していると考えられる.

\section{放射線による正常脳組織の障害}

これまでに報告されている放射線による脳組織の障害 には,

(1)acute brain edema

(2)late delayed radiation necorsis

(3)disseminated necrotizing leukoencephalopathy

(4)subacute radiation-induced leukoencephalopathy

(radiation-induced brain atrophy)

がある. 前二者が，比較的高線量で起こるのに対し，後 二者は比較的低線量で起こりうるのが特徵である。以下， われわれの報告した subacute radiation-induced leukoencephalopathy を中心におのおのについて述べる.

\section{Acute brain edema}

前項でも述べたように照射野内の血管の内皮細胞の障 害により照射直後から急速に血管透過性が方進すること によって起こるものであり, 浮腫の程度は内皮細胞の障 害の程度に比例するため線量依存性である. 実際には, 1 回 $2 \mathrm{~Gy}$ 前後の分割照射の場合には血管内皮の傷害は 軽度であり, 比較的広範囲に照射しても浮腫による頭蓋 内圧の上昇は軽度であるが，1 回 $10 \mathrm{~Gy}$ 以上の照射にな
ると内皮細胞の傷害の程度は著しく, 強度の浮腫が照射 野を越えて拡がるため, 照射野が大きいと致死的な頭蓋 内圧六進をきたしうる ${ }^{5) 15)}$.

\section{Late delayed radiation necrosis}

この病態がいわゆる脳の耐容線量の上限 $(60 \mathrm{~Gy})$ を 規定している。実際に late delayed radiation necrosis は $52.5 \mathrm{~Gy}$ 以下ではまったく認められず，55 Gy では 1.5\%，60 Gy では 4\%，65 Gy では 25\%，67.5 Gy では $100 \%$ 起こるという報告がある ${ }^{1222) 26(31) 35)}$. 成因について は現在のところ主として放射線による血管障害を介した 二次的な変化という説 ${ }^{111771830)}$ と，放射線による直接的 な神経組織の障害という説 ${ }^{37)}$ の二通りがあり, 意見の一 致をみていない。前説の根拠は radiation necrosis の病 理組織学的所見として, 拡張した血管の閉塞像が多数認 められること, 壊死巣が虚血性壊死の組織所見に類似し ていることである ${ }^{6 / 8)}$. 後説では late delayed radiation necrosis は, 例えば肺では照射後 $2 \sim 4$ カ月で出現し, 脳では $1 \sim 5$ 年後に出現するが，これら出現時期の大き な差は血管障害を介した虚血による現象では説明でき ず，組織による放射線感受性の差(細胞ごとの turn over の速さの差）によるものだとして直接障害説を主張して いる。その組織学的所見の特徵は, diffuse な demyelination と血管の変性を伴った白質の necrosis が主体をな していることであり．血管の変化としては拡張やフィブ リノイド変性, 内腔の狭窄扔よび閉塞, 周囲のヒアリン 沈着などが認められる ${ }^{721224272}$. Gliosis の程度は乏しい ものから豊富なものまでさまざまであり，脳梗塞など虚 血性病変では壊死巣周囲にほぼ全例に認められるのと対 照的であり，放射線により，周囲の glial cell も障害さ れている場合があることを示している，50〜60 Gy の照 射を受けて細胞レベルで何らの変化も生じないとも考え にくく，これらの病変は放射線による直接的な変化と， 血管障害による二次的なものを同時に見ている可能性が 高いと考える，幸いに，局所照射方法の進歩により，標 的以外の部位にやむを得ず $50 \sim 60 \mathrm{~Gy}$ 以上の大線量が 照射されることが少なくなった現在，臨床的に以前ほど 問題とならなくなってきた.

\section{Disseminated necrotizing leukoen- cephalopathy $と$ subacute radiation- induced brain atrophy}

両者とも治療家が「脳に対してはまず安全」と考えて いる20〜30 Gy 程度の線量で起こり，重篤な臨床症状を 


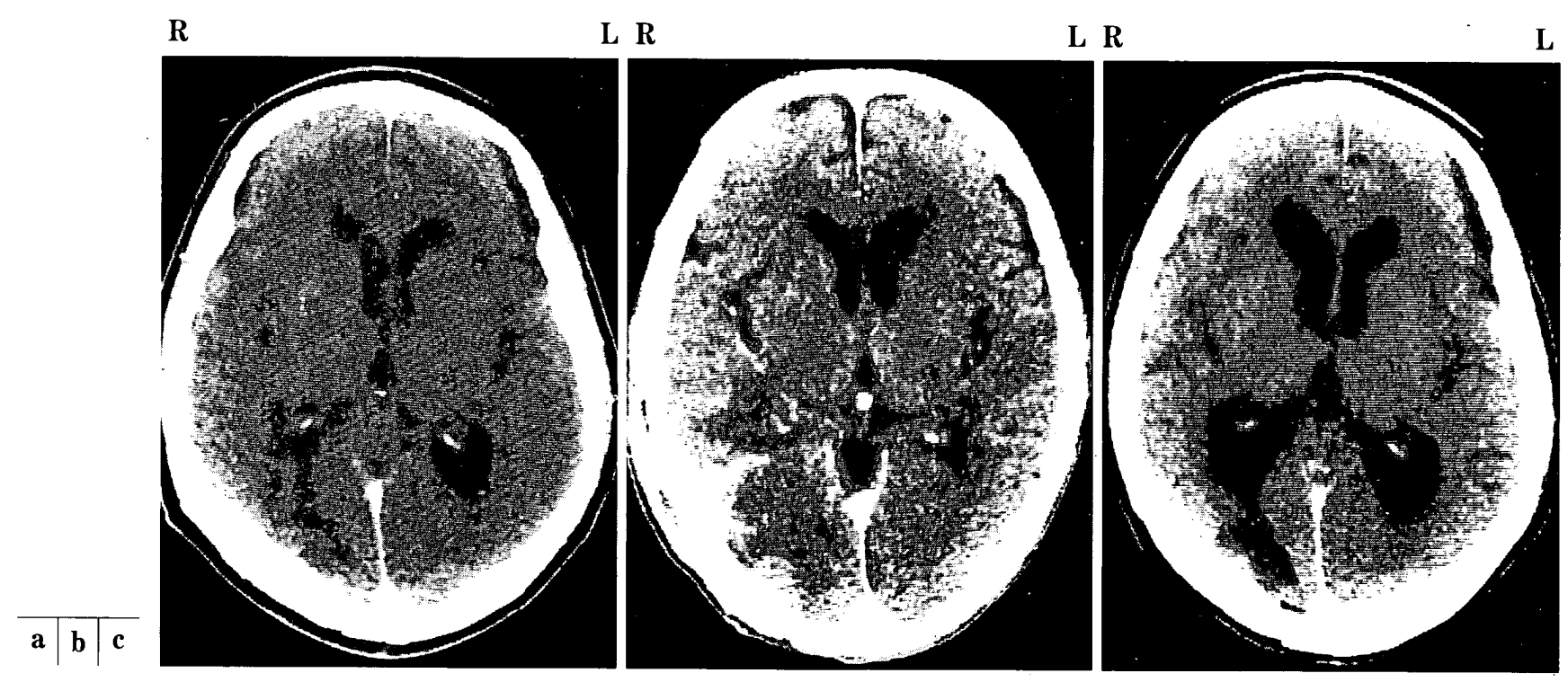

Fig. 1 CT scans showing the progression of radiation-induced brain atrophy : at pre-irradiation (a) ; at 1.5 months (b) ; and at 3 months (c) after radiation therapy

呈しうる点で共通している．前者は発達段階にあり，修 復能が未熟な小児の脳, 後者は修復能が低下した老人の 脳，いずれも放射線に対する感受性が高いと考えられる 脳で発生する．また，両者とも主として全脳照射を含む 広範囲照射後に起こり, 神経症状は局所症状が少なく, 意識低下，精神運動機能の低下 (痴呆) など global な脳 機能の低下が共通して認められる。

Disseminated necrotizing leukoencephalopathy は Rubinstein ら ${ }^{34)}$ や Price ら ${ }^{33}$ によって初めて報告された 放射線障害で，急性リンパ球性白血病の中枢神経系への 浸潤を予防するために行われる全脳照射一メトトレキ セート髄注療法後数力月〜 1 年後に起こってくることが わかった，放射線あるいは化学療法に感受性が高い発育 時期の脳に対して，放射線とメトトレキセートが直接, 相乗的に作用するためと考えられている。組織学的には Rubinstein らの報告したものはいわゆる劇症型といえ るもので，文字どおり白質全体に脱髄があり，斑状の壊 死巣 (coagulative necrosis) が混在するものである. 壊 死巣が主体で late delayed radiation necrosis に類似し ているが，血管の形態の変化やフィブリンの血管外漏出 など, vasogenic な変化に乏しいものも多数ある ${ }^{34)}$. Price らが報告したものの中には軽症型と考えられるも のが含まれる。白質に diffuse な脱髄を認め, oligodendrocyte に胞体の大小不同，核の濃縮，崩壊 (karyorrhexis), 溶解など主たる変化を認めている33. 臨床症状 は痙攣, 進行性の意識障害, 除脳硬直などから, 精神運 動機能の低下, 意識の軽度低下など, 比較的軽い症状が 緩徐に進行するものまであるが，いずれもやがては寝た きりとなり，死に至っている。
われわれの報告した subacute radiation-induced leukoencephalopathy は罹患年齢層, 成因は別として, 臨床 症状, 経過, 組織所見は Price らの報告したものに近い と考えられる ${ }^{2) 41}$. 要約すると, 50 歳以降の中高齢者に対 して全脳照射を含む広範囲放射線照射を施行した際に， $50 \%$ 以上の患者で，照射後数力月〜 1 年の間に，著明な 脳萎縮を伴った進行性の精神運動機能障害あるいは意識 障害の出現を認め (Fig. 1), これらは髄液ドレナージ, シャントなどによって改善されず，重症例ではやがて寝 たきりとなり死に至る。組織学的には, 神経細胞, 血管 組織, 脳室周囲は変化に乏しく, 白質の病変が中心で, 著明な脱髄が認められる。当初は oligodendendrocyte の数の欠落が著明でないため, その形態的変化に注意が いかなかったが, その後, 組織学的検討を重ねるにつれ て, Price らが報告したものに近い oligodendrocyte の 形態的変化, すなわち胞体の大小不同, 核の濃染, chromatid の溶解など (Fig. 2), が存在していたことが 明らかになり, 責任病変が oligodendrocyte にあると考 えるに至っている。

この病態は, 標的線量が $30 \mathrm{~Gy}$ 以上で $50 \%$ 以上の症例 で発現しえ, 照射範囲の大小と, 患者の年齢が予後を決 定する重要な因子となる，成因についてはやはり，放射 線による直接障害あるいは血管透過性の亢進を介した二 次的な障害という二通りが考えられている。脳組織を構 成する細胞のうち, 比較的放射線感受性の高いものは血 管内皮と oligodendrocyte であり，前者は $30 \mathrm{~Gy}$ で十分 障害されえ ${ }^{19)}$ ，血管透過性が穴進したりあるいは血液脳 関門が破壊されれば, 神経組織が血中の有害物質にさら されることになり, 細胞が障害されうる。しかし，この 


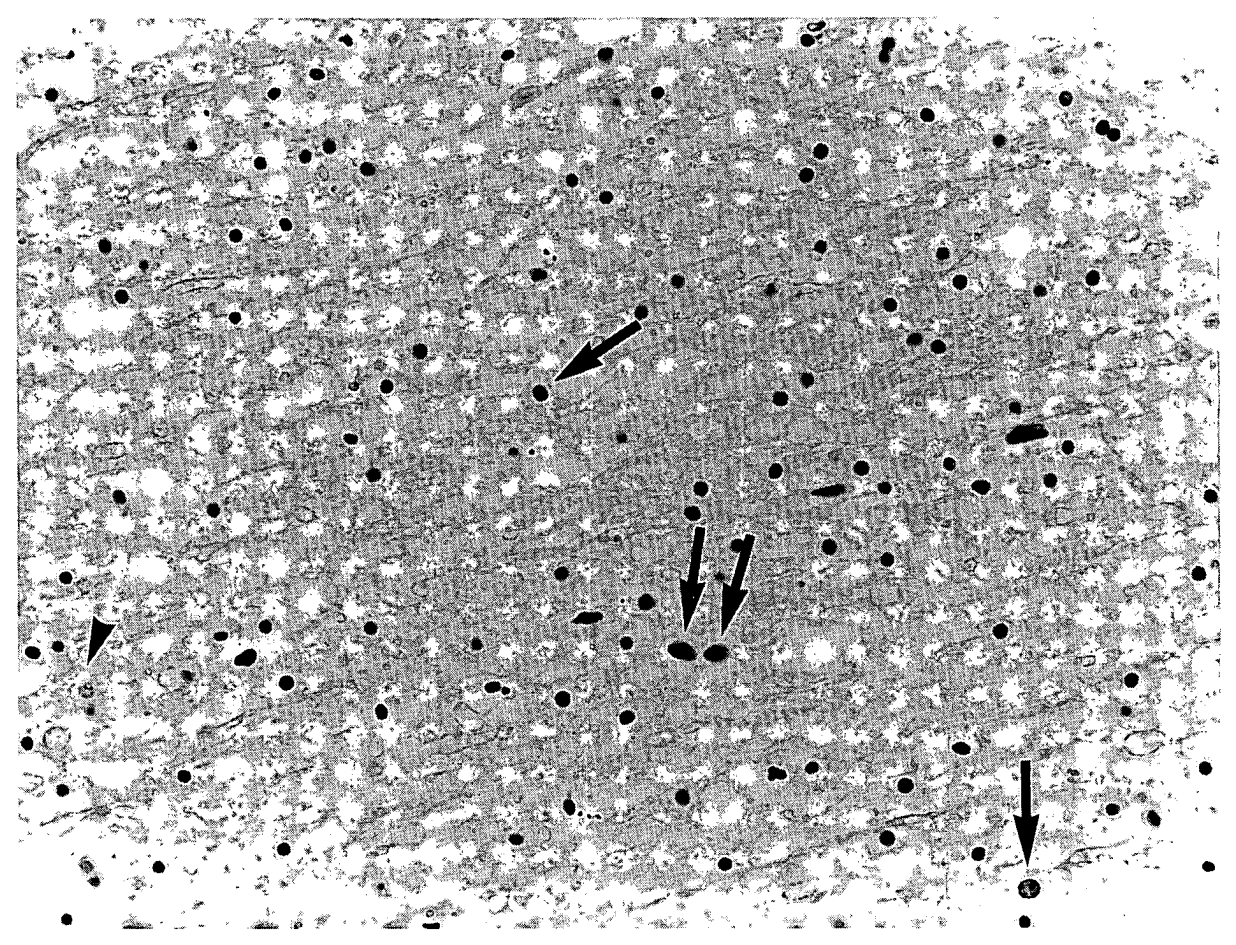

Fig. 2 Photomicrograph showing irregular-shaped, pyknotic nuclei of verious size oligodendrocytes (arrows) and the residual, normal-shaped nucleu$s$ of oligodendrocytes (arrow head) (Klüver-Barrera, $\times 400$ )

場合, 細胞全般，特に神経細胞にも変化が認められるは ずであり, oligodendrocyte のみに変化が認められる実 際の所見と合致しない. 渉漁しえたかぎりでは, $30 \mathrm{~Gy}$ の 照射で oligodendrocyte に傷害が起こるか否か，実験的 に裏付ける報告は見いだせなかったが，実際に臨床的に 1 回 $2 \mathrm{~Gy}$, 計 $30 \mathrm{~Gy}$ の分割照射で oligodendrocyte に選 択的に先に述べたような変化が起こるわけであり, Rubinstein ら，Price らの報告もあわせて考えると，放 射線による直接的な oligodendrocyte の傷害が本病態の 原因と考えられる.

本病態は CT の出現によって, 剖検では確認できない 程度の脳萎縮でも経時的に検出することができるように なり，また，悪性脳腫瘍の治療後再発までの期間が延び て，これまで再発と重なってマスクされていた臨床症状 が顕著に認められるようになったために，放射線による 正常脳の障害として新たに認为られるようになったと考 えられる、最後に，この病態は治療上汎用する線量範囲 内で発現するものであり，言いかえれば治療家がその存 在を知って予防しなければ必発であることを強調した い.

\section{まとめ}

以上，放射線治療に伴う正常脳の障害について解説し た.
腫瘍再発のパターンをみたとき，グリオーマの 90\%以 上で原発巣に連続した部分に再発が起こること ${ }^{16)}$ ，また， 転移性脳腫瘍に扔いて $30 \mathrm{~Gy}$ 程度の線量で将来的な転 移巣形成を予防できるか否か疑問であることなどから， 局所の腫瘍を消極的に切除し, 正常脳を含む広範囲に放 射線照射を施行することは, 治療効果の面から考えても はなはだ疑問である。したがって, 冒頭にも述べたが, 悪性脳腫瘍の治療にも“生存の質”を加味することが求 められるようになっている今日，悪性脳腫瘍の治療の基 本原則を先に述べた現行のものから「手術でできるかぎ り腫場を切除し，残存部㧍よびその周囲の局所浸潤部に 限って最大限の放射線を照射し，徹底的に局所をたたく」 というものに変えることが必要であり, あわせて, 治療 効果に負の要因として働くこの subacute radiation-induced leukoencephalopathy の発症を予防するために も, 腫場の組織型, 大きさ等はもちろんのこと, 年齢層 に応じた照射範囲の基準を設定するなどの “きめ”の細 かいプロトコール作りが必要であると考えられる.

\section{文 献}

1) Adamson IYR, Bowden DH : Endothelial injury and repair in radiation-induced pulmonary fibrosis. $\mathrm{Am}$ $J$ Pathol $112:$ :224-230, 1983.

2）浅井昭雄, 松谷雅生, 高倉公朋: 脳腫瘍放射線治療後の 亜急性障害としての脳萎縮と痴呆. 癌の臨床 33 ： 753-761, 1987.

3) Asai A, Matsutani M, Kohno T, Nakamura O, Tana- 
ka H, Fujimaki T, Funada N, Matsuda T, Nagata K, Takakura K : Subacute brain atrophy after radia. tion therapy for malignant brain tumor. Cancer 63: 1962-1974, 1989.

4) 浅井昭雄, 松谷雅生, 松田忠義, 田中良明, 船田信顕： 放射線性脳萎縮の臨床組織学的検討. 癌の臨床 35 ： 1325-1329, 1989.

5) Brown DG, Sasmore DP, Jones LP: Acute central nervous system syndrome in burros. in Haley $\mathrm{S}$ (ed) : Response of the nervous system to ionizing radiation. New York, Academic Press, 1962, pp. 503 -512 .

6) Davis RL : Brain response to combined modality therapy. Front Radiat Ther Oncol $13: 58-66,1979$.

7) Diengdoh JV, Booth AE : Postirradiation necrosis of the temporal lobe presenting as a glioma. $J$ Neuro. surg 44:732-734, 1976

8) Duchen LW: General pathology of neurons and neuroglia. in Adams JH, Corsellis JAN, Duchen LW (eds) : Greenfield's Neuropathology, 4th ed. New York, John Wiley \& Sons, 1984, pp. 1-52.

9) Evans ML, Graham MM, Mahler PA, Rasey JS : Changes in vascular permeability following thorax irradiation in the rat. Radiat Res 107:262-271, 1986.

10) Fajardo LF, Stewart JR : Pathogenesis of radiationinduced myocardial fibrosis. Lab Invest $29: 244$ $-257,1973$.

11) Fajardo LF : The unique physiology of endothelial cells and its implications in radiobiology. Front Radiat Ther Oncol 23:96-112, 1989.

12) Griem ML : Clinical radiation tolerance of brain, spinal cord and peripheral nerves. Laboratory and patient data as clinical guides. Front Radiat Ther Oncol 23:367-389, 1989.

13) Gross NJ : Experimental radiation pneumonitis. IV. Leakage of circulatory proteins onto the alveolar surface. J Lab Clin Med 95 : 19-31, 1980.

14) Hall EJ : Radiobiology for the radiologist, 2nd ed., Hagertown, Medical Department Harper \& Row Publishers Inc., 1978.

15) Hindo WA, De Trana FA, Lee MS, Hendrickson FR : Large dose increment irradiation in treatment of cerebral metastasis. Cancer 26:138-141, 1970.

16) Hochberg FH, Pruitt $A$ : Assumptions in the radiotherapy of glioblastoma. Neurology $30: 907-911$, 1980.

17) Hopewell JW, Young CMA: Changes in the microcirculation of normal tissues after irradiation. Int J Radiat Oncol Biol Phys 4:53-58, 1978.

18) Hopewell JW : Late radiation damage to the central nervous system-A radiobiological interpretation. Neuropathol Appl Neurobiol 15:329-343, 1979.

19) Johnson L, Longenecker JP, Fajardo LF : Differential radiation response of cultured endothelial cells and smooth myocytes. Anal Quant Cyto 14:188 $-198,1982$.

20) Jolles B, Harrison RG: Enzymatic processes and vascular changes in the skin radiation reaction. $\mathrm{BrJ}$ Radiol 39 : 12-18, 1966.
21) Kagan AR, Steckel RJ, Cancilla P, Julliard G, Patin $\mathrm{T}$ : The pathogenesis of brain necrosis: time and dose parameters. Int Radiat Oncol Biol Phys 1:729 $-732,1976$.

22) Kramer S, Southard ME, Mansfield CM : Radiation effects and tolerance of the central nervous system. Front Radiat Ther Oncol 6:332-345, 1972.

23) Law MP, Thomlinson RH : Vascular permeability in the ears of rats after X-irradiation. $\mathrm{Br} J$ Radiol 51: 895-904, 1978.

24) Llena JF, Cespedes G, Hirano A, Zimmerman HM, Feiring EH, Fine D : Vascular alterations in delayed radiation necrosis of the brain. Arch Pathol 100 : 531-534, 1976.

25) Maisin JR : The influence of radiation on blood vessels and circulation. III. Ultrastructure of the vessel wall. Curr Top Radiat Res $10: 29-57,1974$.

26）松谷雅生, 河野 武, 中村 治, 浅井昭雄, 田中秀樹: Glioblastoma に対する術中照射療法. 最新医学 41 : 1506-1513, 1986.

27) Marks JE, Baglan RJ, Prasad SC, Blank WA : Cerebral radiationecrosis: incidence and risk in relation to dose, time, fractionation and volume. Int Radiat Oncol Biol Phys $7: 243-252,1981$.

28) Marins AN, Johnston JS, Henry JM, Stoffel TJ, Di Chiro G : Delayed radiation necrosis of the brain. $J$ Neurosurg $47: 336-345,1977$

29) Mount D, Bruce WR: Local plasma volume and vascular permeability of rabbit skin after irradiation. Radiat Res 23:430-445, 1964.

30) Pennybacker J, Russell DS : Necrosis of the brain due to radiation therapy: Clinical and pathological observation. J Neurol Neurosurg Psychiatry 11:183 $-198,1948$.

31) Pezner RD, Archambeau JO : Brain tolerance unit: a method to estimate risk of radiation brain injury for various dose schedules. Int Radiat Oncol Biol Phys 7:397-402, 1981.

32) Phillips TL : An ultrastructural study of the development of radiation injury in the lung. Radiology 87 : 49-54, 1966.

33) Price RA, Jamieson PA : The central nervous system in childhood leukemia. II. Subacute leukoencephalopathy. Cancer 35:306-318, 1975.

34) Rubinstein LJ, Herman MM, Long TF, Wilbur JR : Disseminated necrotizing leukoencephalopathy : a complication of treated central nervous system leukemia and lymphoma. Cancer 35:291-305, 1975.

35) Sheline GE, Wara WM, Smith V: Therapeutic irradiation and brain injury. Int $J$ Radiat Oncol Biol Phys 6:1215-1228, 1980.

36) Takakura K, Abe H, Tanaka R, Kitamura K, Miwa T, Takeuchi K, Yamamoto S, Kageyama N, Handa H, Mogami H, Nishimoto A, Uozumi T,Matsutani M, Nomura K : Effects of ACNU and radiotherapy on malignant glioma. J Neurosurg 64:53-57, 1986.

37) Withers HR, Peters LJ, Kogelnik HD : The pathobiology of late effects of irradiation. in Meyn RE, Withers HR (eds): Radiation Biology in Cancer Research. New York, Raven Press, 1980, pp. 439-448. 
要

旨

放射線治療に伴う正常脳組織障害

浅井 昭雄 松谷 雅生 高倉 公朋

従来から放射線障害として知られている acute brain edema および late delayed radiation necrosis については治療家が十分に認識し, その予防に配慮しているのて, 今曰臨床的に問 題になることは少なくなった反面, 最近になってその存在が明らかになってきた subacute radiation-induced leukoencephalopathy (radiation-induced brain atrophy) は治㞠 に使う範囲内の低線量でも発現しうるのて, 治療家がその存在を知って放射線治療にあたらなければ 必発であるといえる. この病態の合併を予防しつつ覀性脳腫瘍の治療に臨むことガ治療の質的向上に 重要であると考えられた. この subacute radiation-induced leukoencephalopathy を 中心に, 放射線による細胞傷害の一般的なメカ二ズし, 放射線治療に伴う正常脳の障害について, 文 献および自験データに基ついて解説した。

脳外誌 $1: 116-122,1992$

\section{会員の皆様へ}

\section{1. 入会で案内}

日本脳神経外科コングレス事務局

入会申し込み書一式は，電話あるいは葉書にて事務局までご請求ください，現在の入会金・年会費 は, 以下の通りです。

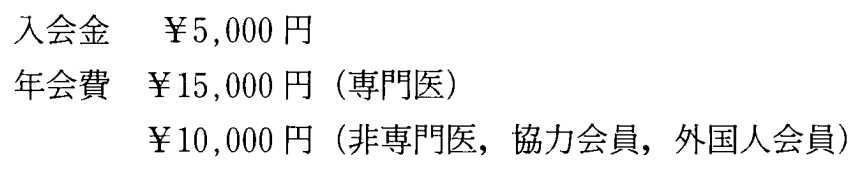

\section{2. 会費の納入時期について}

日本脳神経外科コングレスの総会以後に新しい年度の会費を納入していただくことになっています が，機関誌発行を円滑にするために，総会の開かれた年の年末までに当該年度の会費を納入するよう ご協力ください.

\section{3. 転居・転任される方へ}

速やかに学会事務局までご一報ください.

\section{Neurosurgeons バッワナンバー申込みについて}

講演録 “Neurosurgeons” Vol. 5 10 亿若干在庫がございますので，ご希望の方は事務局までお申 込みください。

連絡先： 7113 東京都文京区本郷 2-1-1

順天堂大学医学部脳神経外科

TEL $03-3813-1039$

FAX $03-5684-3096$ 